\title{
Methylprednisolone Protects Oligodendrocytes But Not Neurons after Spinal Cord Injury
}

\author{
Jin-Moo Lee, ${ }^{1}$ Ping Yan, ${ }^{1}$ Qingli Xiao, ${ }^{1}$ Shawei Chen, ${ }^{2}$ Kuang-Yung Lee, ${ }^{1}$ Chung Y. Hsu, ${ }^{3}$ and Jan Xu ${ }^{1}$ \\ ${ }^{1}$ The Hope Center for Neurological Disorders and Department of Neurology, and ${ }^{2}$ Department of Molecular Biology and Pharmacology, Washington \\ University School of Medicine, St. Louis, Missouri 63110, and ${ }^{3}$ Taipei Medical University, Taipei City, Taiwan, 110
}

\begin{abstract}
Methylprednisolone (MP) is used to treat a variety of neurological disorders involving white matter injury, including multiple sclerosis, acute disseminated encephalomyelitis, and spinal cord injury (SCI). Although its mechanism of action has been attributed to antiinflammatory or antioxidant properties, we examined the possibility that MP may have direct neuroprotective activities. Neurons and oligodendrocytes treated with AMPA or staurosporine died within $24 \mathrm{~h}$ after treatment. MP attenuated oligodendrocyte death in a dose-dependent manner; however, neurons were not rescued by the same doses of MP. This protective effect was reversed by the glucocorticoid receptor (GR) antagonist (11, 17)-11-[4-(dimethylamino)phenyl]-17-hydroxy-17-(1-propynyl)estra-4,9-dien-3-one (RU486) and small interfering RNA directed against GR, suggesting a receptor-dependent mechanism. MP reversed AMPA-induced decreases in the expression of anti-apoptotic Bcl- $\mathrm{x}_{\mathrm{L}}$, caspase-3 activation, and DNA laddering, suggesting anti-apoptotic activity in oligodendrocytes. To examine whether MP demonstrated this selective protection in vivo, neuronal and oligodendrocyte survival was assessed in rats subjected to spinal cord injury (SCI); groups of rats were treated with or without MP in the presence or absence of RU486. Eight days after SCI, MP significantly increased oligodendrocytes (CC-1-immunoreactive cells) after SCI, but neuronal (neuronal-specific nuclear protein-immunoreactive cells) number remained unchanged; RU486 reversed this protective effect. MP also inhibited SCIinduced decreases in Bcl- $\mathrm{x}_{\mathrm{L}}$ and caspase-3 activation. Consistent with these findings, the volume of demyelination, assessed by Luxol fast blue staining, was attenuated by MP and reversed by RU486. These results suggest that MP selectively inhibits oligodendrocyte but not neuronal cell death via a receptor-mediated action and may be a mechanism for its limited protective effect after SCI.
\end{abstract}

Key words: spinal cord injury; oligodendrocytes; neurons; glucocorticoids; methylprednisolone; apoptosis

\section{Introduction}

Methylprednisolone (MP), a synthetic glucocorticoid (GC) agonist with potent anti-inflammatory and antioxidant properties, is the mainstay of therapy for a variety of neurological disorders involving white matter injury. For example, MP is routinely used to treat multiple sclerosis (MS) exacerbations and acute disseminated encephalopmyelitis. It is widely used for acute spinal cord injury (SCI) in which white matter injury plays a prominent but not exclusive role, though marginal efficacy and a poor side-effect profile have recently raised concerns (Nesathurai, 1998; Sayer et al., 2006). Despite its entrenched role in therapy for these disorders, the mechanisms of action of MP are not well understood. Because of the high doses required for protection, it has been proposed that the action of MP is through a receptorindependent inhibition of oxygen-free radical-induced lipid peroxidation (Demopoulos et al., 1982; Hall and Braughler, 1982;

Received June 7, 2007; revised Jan. 25, 2008; accepted Jan. 30, 2008.

This work was supported by National Institutes of Health/National Institute of Neurological Disorders and Stroke Grants R01 NS40525, NS48283, P01 NS32636 (J.-M.L.), and R01 NS40162 (J.X.). Technical assistance was provided by the In Vivo Animal Model Core from the Hope Center for Neurological Disorders.

J.M.-L. and P.Y. contributed equally to this work.

Correspondence should be addressed to Dr. Jan Xu, Department of Neurology, Washington University School of Medicine, 660 South Euclid Avenue, Campus Box 8111, St. Louis, M0 63110. E-mail: xuj@neuro.wustl.edu. DOI:10.1523/JNEUROSCI.5547-07.2008

Copyright $\odot 2008$ Society for Neuroscience $\quad$ 0270-6474/08/283141-09\$15.00/0
Anderson and Means, 1985; Bracken, 1991). The potent antiinflammatory activity of MP (Barnes, 1998) suggests another mechanism that may be more prominent in the treatment of MS. In animal models of inflammatory disorders, GCs have been shown to reduce eicosanoid formation (Perkins and Kniss, 1997) and inhibit the expression of cytokines (Arzt et al., 1994), adhesion molecules (van de Stolpe et al., 1994), inducible nitric oxide synthase (Brenner et al., 1994), and COX2 (Lukiw et al., 1998) and other effector actions of inflammatory mediators (Heyderman et al., 1995; Funk et al., 1995). In addition, GCs induce apoptosis in thymocytes, $\mathrm{T}$ and $\mathrm{B}$ lymphocytes, and peripheral blood monocytes (Sikora, 1966; Schmidt et al., 1999).

Although GCs are best known for their proapoptotic activities in inflammatory blood cells, there are increasing examples of antiapoptotic actions in other cell types. For example, the GR agonist dexamethasone (DEX) attenuated tumor necrosis factor$\alpha$-induced apoptosis of the human mammary carcinoma cell line MCF-7 by preventing the downregulation of inhibitors of apoptosis family of proteins (Messmer et al., 2001). Dexamethasone also suppressed proapoptotic $\mathrm{Bcl}-\mathrm{x}_{\mathrm{S}}$ expression and enhanced basal levels of antiapoptotic Bcl- $\mathrm{x}_{\mathrm{L}}$ in gastric cancer TMK-1 cells (Chang et al., 1997) and C6 glioma cells (Ni Chonghaile et al., 2006), enhancing cell survival. Moreover, spontaneous apoptosis in primary cultures of human and rat hepatocytes was inhibited 
by dexamethasone, in parallel with an increase in Bcl- $\mathrm{x}_{\mathrm{L}}$ expression (Bailly-Maitre et al., 2001).

Several studies have reported that, after SCI, some neural cells die with features of apoptosis (Crowe et al., 1997; Liu et al., 1997; Springer et al., 2001). Ultrastructural features, biochemical markers, and activated apoptotic mediators or end products have been observed in contused cords (Hamada et al., 1996; Crowe et al., 1997; Liu et al., 1997; Emery et al., 1998; Springer et al., 1999; Li et al., 2000; Keane et al., 2001). Prominent among these dying cells were oligodendrocytes, which were observed to die hours to weeks after injury near and distant to the epicenter (Crowe et al., 1997; Shuman et al., 1997; Yong et al., 1998; McTigue et al., 2001; McEwen and Springer, 2005).

In light of its contrasting apoptotic activities in different cell types, we investigated whether MP could have differential antiapoptotic activities in neural cells after SCI.

\section{Materials and Methods}

SCI model in rats

The SCI model in rats has been detailed previously (Xu et al., 1990, 1991, 1992, 1998a; Liu et al., 1997). Briefly, female rats (Long-Evans, body weight of $300 \pm 25 \mathrm{~g}$ ) were subjected to chloral hydrate anesthesia ( $400 \mathrm{mg} / \mathrm{kg}$, i.p.). After a T9-T11 laminectomy, SCI was induced using a New York University (NYU) Impactor by dropping a $10 \mathrm{~g}$ weight at a height of $12.5 \mathrm{~mm}$. Animals subjected to identical surgical procedures, without impaction, served as shamoperated controls. In some situations, animals undergoing no surgery were used as controls. Perioperative care followed MASCIS (Multicenter Animal Spinal Cord Injury Study) guidelines, which has been described in previous publications (Basso et al., 1996; Liu et al., 1997; Xu et al., 1998a). In addition, all procedures were approved by the Washington University Animal Studies Committee.

\section{Cell culture}

Cortical neuronal cultures. Cortical neuronal cultures were prepared as described (Rose et al., 1990). Briefly, cortices were isolated from 14-16 d rat embryos, dissociated, and plated on poly-lysine-coated dishes or 24well plates in MEM (with glutamine-free Earle's salts) supplemented with $5 \%$ fetal bovine serum, $5 \%$ horse serum, $20 \mathrm{~mm}$ glucose, and $2 \mathrm{~mm}$ glutamine. After $3 \mathrm{~d}$ in vitro, non-neuronal cells were eliminated with a $3 \mathrm{~d}$ exposure to $10 \mu \mathrm{M}$ cytosine arabinoside, yielding $>90 \%$ pure neuronal cultures. Cultures were maintained in a $37^{\circ} \mathrm{C}$ humidified incubator in a $5 \% \mathrm{CO}_{2}$ atmosphere.

Oligodendrocyte cultures. Neurospheres were cultured as described previously (Zhang et al., 1999) with modifications. Briefly, embryonic rat cortices (embryonic days 14-16) were dissected, homogenized gently in $\mathrm{DMEM} / \mathrm{F}-12$ medium, and centrifuged at $350 \times \mathrm{g}$ for $5 \mathrm{~min}$. The pellet was digested with $1.5 \mathrm{ml}$ of $0.025 \%$ trypsin $/ 0.27 \mathrm{~mm}$ EDTA at $37^{\circ} \mathrm{C}$ for 30 min followed by the addition of $1.5 \mathrm{ml}$ DMEM/F-12 with $20 \%$ FBS and then filtered through $10 \mu \mathrm{m}$ nylon mesh. The filtrate was centrifuged at $350 \times g$ for $5 \mathrm{~min}$, and the pellet was washed twice with DMEM/F-12. Dissociated cells were layered on a preequilibrated Percoll gradient (formed by centrifuging 50\% Percoll and 50\% DMEM/F-12 at 23,500 $\times$ $g$ for $1 \mathrm{~h}$ at $4^{\circ} \mathrm{C}$ ) and centrifuged at $23,500 \times g$ for $15 \mathrm{~min}$. The fraction containing glial progenitors, banding between myelin and red blood cell layers, were recovered and washed twice with DMEM/F-12 followed by a

\section{Oligodendrocytes}

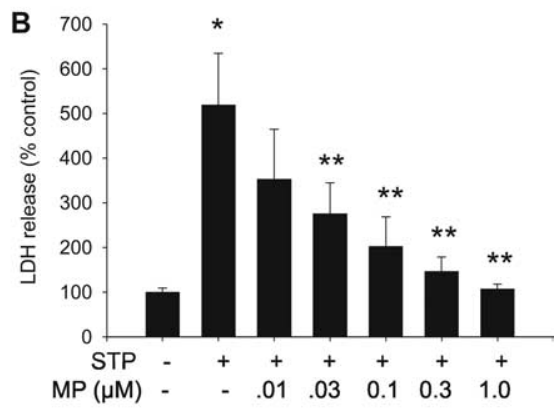

Neurons

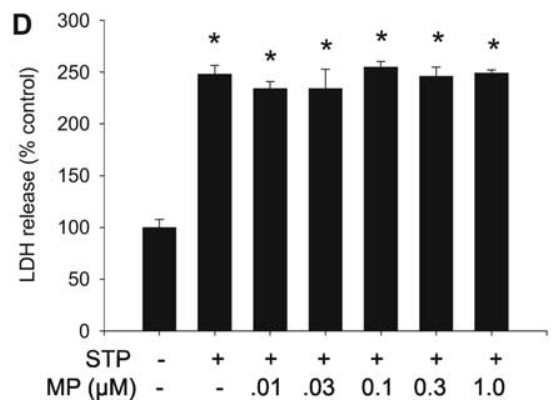

Figure 1. MP selectively attenuates oligodendrocyte cell death. $\boldsymbol{A}-\boldsymbol{D}, 0$ ligodendrocytes $(\boldsymbol{A}, \boldsymbol{B})$ or neurons $(\boldsymbol{C}, \boldsymbol{D})$ grown in the presence or absence of AMPA (200 $\mu \mathrm{M})$ plus cyclothiazide $(100 \mu \mathrm{m})$ or STP $(0.2 \mu \mathrm{m})$ were pretreated for $2 \mathrm{~h}$ with vehicle, luced by treatment with AMPA or STP was attenuated by MP $(A)$ in a STP-induced cell death for both cell types $\left(\boldsymbol{A}, \boldsymbol{C}^{*} \mathrm{*}<0.01\right.$ compared with control.**p $<0.05$ compared with STP or AMPA treatment a experiments, using triplicate cultures in each group.

wash with neurosphere culture medium (DMEM/F-12, N1 supplement, $25 \mu \mathrm{g} / \mathrm{ml}$ insulin, $20 \mathrm{ng} / \mathrm{ml}$ basic fibroblast growth factor, and $20 \mathrm{ng} / \mathrm{ml}$ epidermal growth factor). The cell pellet was resuspended in $20 \mathrm{ml}$ of neurosphere culture medium and seeded in $75 \mathrm{~mm}$ culture flasks. After $24 \mathrm{~h}$, when neurospheres formed, $5 \mathrm{ml}$ of fresh medium was added to each culture every other day for $7 \mathrm{~d}$; the neurosphere cultures were split (1:2), dissociated gently 10 times with a syringe with needle (25 gauge), and centrifuged at $350 \times g$. The resulting cell pellets were treated with $0.05 \%$ trypsin $/ 0.53 \mathrm{~mm}$ EDTA and centrifuged at $350 \times g$ for $10 \mathrm{~min}$. The cells were resuspended in progenitor medium (69\% DMEM/F-12 containing N1 supplement, $10 \mu \mathrm{g} / \mathrm{ml}$ insulin, $20 \mathrm{~nm}$ progesterone, $100 \mathrm{U}$ of penicillin/streptomycin, $30 \%$ conditioned medium from B104 cells, and $1 \% \mathrm{FBS}$ ) and plated on $100 \mathrm{~mm}$ culture dishes precoated with poly-Lornithine. Disaggregated oligosphere cells displayed bipolar or tripolar morphology.

For differentiated oligodendrocyte cultures, progenitor cells were detached with trypsin and cultured on poly-L-ornithine-coated dishes in differentiating oligodendrocyte medium (DMEM/F-12, N1 supplement, $20 \mathrm{ng} / \mathrm{ml}$ biotin, $20 \mathrm{ng} / \mathrm{ml}$ triiodo-L-thyronine, $20 \mathrm{ng} / \mathrm{ml}$ retinoic acid, 0.1 $\mu \mathrm{g} / \mathrm{ml}$ heregulin $1-\beta$, and $1 \% \mathrm{FBS})$. We have shown previously that oligoprogenitor cells differentiated from rat neurospheres demonstrate morphologic and antigenic characteristics of oligodendrocytes; immunohistochemistry revealed that virtually all cells immunostained for oligodendrocyte-specific antigens, CNP, Rip, GalC, and proteolipid protein (Lee et al., 2004).

Cell death assessment. Cell viability was quantitated by the lactate dehydrogenase (LDH) assay (Xu et al., 1998b).

\section{DNA fragmentation}

DNA laddering (Xu et al., 1998a). Briefly, at various intervals after injury, a $10 \mathrm{~mm}$ spinal cord segment $(5 \mathrm{~mm}$ rostral and $5 \mathrm{~mm}$ caudal from the epicenter) was dissected after intracardiac perfusion with $100 \mathrm{ml}$ of saline 

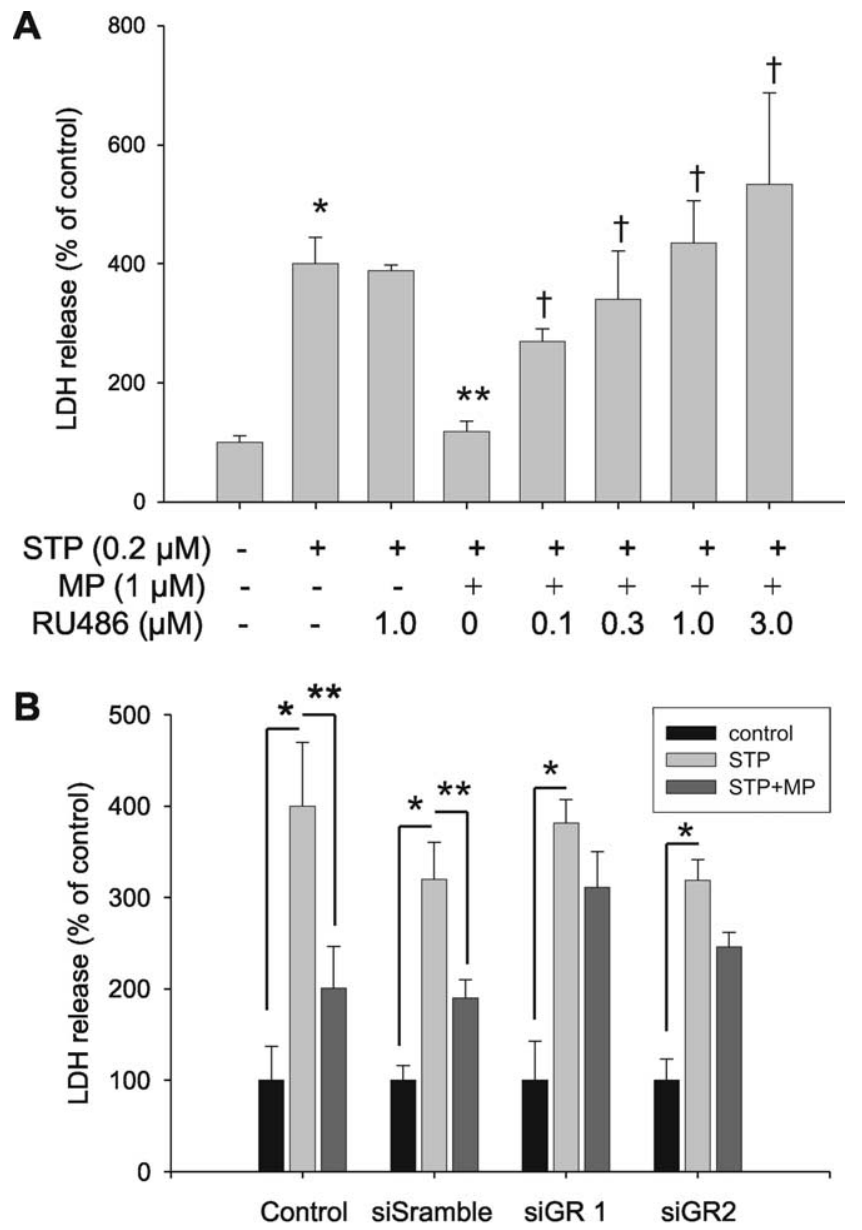

C

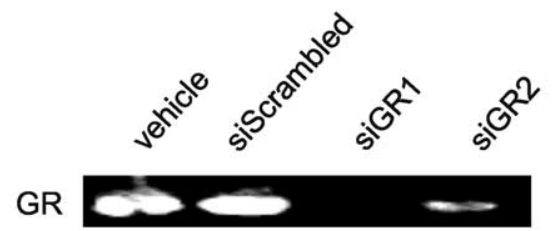

cyclophilin

Figure 2. The protective effect of MP is mediated by the glucocorticoid receptor. $A$, Oligodendrocytes grown in the presence or absence of STP $(0.2 \mu \mathrm{M})$ and/or MP were treated with escalating doses of the glucocorticoid receptor antagonist RU486 and assessed for cell death by LDH release. RU486 inhibited the protective activity of MP in a dose-dependent manner. ${ }^{*} p<$ 0.001 compared with control; ${ }^{* *} p<0.001$ compared with STP treatment; ${ }^{\dagger} p<0.001$ compared with STP plus MP treatment (ANOVA with post hoc Tukey's test). B, Oligodendrocytes grown in the presence or absence of vehicle, scrambled siRNA, or two different siRNAs directed against GR were treated with STP or MP as indicated and assessed for cell death. Transfection efficiencies were $85-90 \% .{ }^{*} p<0.001$ control versus STP; ${ }^{* *} p<0.001$ STP versus MP plus STP (ANOVA with post hoc Tukey's test). Error bars represent SD. Results were replicated in two independent experiments, using triplicate cultures in each group. Both GR siRNAs (50 nM) attenuated the protective effect of MP $(\boldsymbol{B})$, concomitant with GR mRNA knockdown (C).

under anesthesia. In cultures, oligodendrocytes were collected after drug treatments. The samples were homogenized in lysis buffer $(50 \mathrm{~mm}$ Tris$\mathrm{HCl}, 10 \mathrm{~mm}$ EDTA, and $0.5 \%$ SDS, $\mathrm{pH} 8.0)$, incubated with RNase $(0.5$ $\mathrm{mg} / \mathrm{ml})$ at $55^{\circ} \mathrm{C}$ for $1 \mathrm{~h}$, followed by proteinase $\mathrm{K}(0.5 \mathrm{mg} / \mathrm{ml})$ at $37^{\circ} \mathrm{C}$ overnight. The solution was extracted with the same volume of phenol and chloroform $(1: 1, \mathrm{v} / \mathrm{v})$ and centrifuged at $25,000 \times \mathrm{g}$ at room temperature for $10 \mathrm{~min}$. Equal volumes of isopropanol was added to the supernatant and centrifuged at $13,000 \times g$ for $15 \mathrm{~min}$. Pellets were washed with $70 \%$ ethanol, rehydrated with Tris-EDTA buffer, electrophoresed on a $1.5 \%$ agarose gel, and visualized by UV for quantification.
ELISA. For cultures, oligodendrocytes were collected after drug treatment. The cytosolic levels of histone-associated DNA fragments were determined using a Cell Death Detection ELISA kit (Roche Diagnostics, Mannheim, Germany) (Xu et al., 1998a).

\section{Small interfering RNA}

Two small interfering RNAs (siRNAs) were acquired to knockdown GR (Qiagen, Valencia, CA): siGR1, sense, r(GAU GUU AGG UGG GCG UCA A)dTdT; antisense, r(UUG ACG CCC ACC UAA CAU G)dTdT; target sequence, AAC ATG TTA GGT GGG CGT CAA; and siGR2, sense, r(GGG ACA AAU AUA AUU GGU A)dTdT; antisense, r(UAC CAA UUA UAU UUG UCC C)dAdG; target sequence, CTG GGA CAA ATA TAA TTG GTA. A nonspecific duplex was used as a control siRNA [5' r(CAG UGG AGA UCA ACG UGC AAG UU)-3'], which did not affect GR mRNA levels relative to the untransfected controls. siRNAs in OptiMEM medium was mixed with Lipofectamine 2000 in Opti-MEM medium (Invitrogen, Carlsbad, CA) for $20 \mathrm{~min}$ and then added to oligodendrocyte cultures (without antibiotics) for $48 \mathrm{~h}$ (final concentration, 50$200 \mathrm{nM})$. After transfection, medium was changed to DMEM/F-12, and MP ( $1 \mu \mathrm{M})$ was added for $4 \mathrm{~h}$ followed by staurosporine (STP) (100 nM) for $24 \mathrm{~h}$. LDH from the medium was measured for cytotoxicity.

\section{Western blot analysis}

This method has been reported previously (Xu et al., 1991, 1997, 1998a). Briefly, at various intervals after injury, a $10 \mathrm{~mm}$ spinal cord segment (5 $\mathrm{mm}$ rostral and $5 \mathrm{~mm}$ caudal from the epicenter) was dissected after intracardiac perfusion with $100 \mathrm{ml}$ of saline. The cord segment was homogenized in Western blot buffer $(10 \mathrm{~mm}$ Tris- $\mathrm{HCl}$ containing $10 \mathrm{~mm}$ HEPES, $1.5 \mathrm{~mm} \mathrm{MgCl}, 10 \mathrm{~mm} \mathrm{KCl}, 0.5 \mathrm{~mm}$ DTT, 1 mм PMSF, and 0.1 $\mathrm{U} / \mathrm{ml}$ protinin, $\mathrm{pH} 7.9)$ and centrifuged at $600 \times \mathrm{g}$. The pellets were collected for nuclear protein extraction (see below). The supernatant (cytoplasm) was subjected to high-speed $(25,000 \times g)$ centrifugation. Protein $(20-60 \mu \mathrm{g})$ from the supernatant was loaded onto $10-12 \%$ polyacrylamide gel (depending on protein molecular weight), separated by SDS/PAGE, and transferred to nitrocellulose membranes by electrophoresis. The membranes were blocked in TBST buffer containing 20 mu Tris- $\mathrm{HCl}, 5 \%$ nonfat milk, $150 \mathrm{~mm} \mathrm{NaCl}$, and $0.05 \%$ Tween 20 , pH 7.5, for $1 \mathrm{~h}$ at room temperature. Primary antibodies, anti-activated caspase-3 (1:500; Cell Signaling Technology, Beverly, MA), anti-Bcl- $\mathrm{x}_{\mathrm{L}}$ (1:1000; Sigma, St. Louis, MO), anti- neuronal-specific nuclear protein (NeuN) (1:500; Millipore Bioscence Research Reagents, Temecula, CA), and anti-myelin basic protein (MBP) (1:1000; Millipore Bioscience Research Reagents), were added to the membrane and incubated at $4^{\circ} \mathrm{C}$ overnight. The membrane was washed with TBST, incubated with alkaline phosphatase- or horseradish peroxidase-conjugated anti-rabbit, anti-mouse, or anti-rat secondary antibody (1:5000) at room temperature for $1 \mathrm{~h}$, and detected using the Blot AP System (Promega, Madison, WI) or SuperSignal West Pico Chemiluminescent Substrate System (Pierce) as described in the technical manual provided by the manufacturers.

\section{Immunohistochemistry}

Rats were killed at various times after injury under anesthesia and perfused transcardially with $100 \mathrm{ml}$ of $0.9 \%$ saline followed by $500 \mathrm{ml}$ of $4 \%$ paraformaldehyde (Holets et al., 1987; Xu et al., 1995). After perfusion, the spinal cords were carefully dissected, and $10 \mathrm{~mm}$ segments centered at the epicenter were blocked and postfixed for an additional $2 \mathrm{~h}$ in the same fixative. The specimens were transferred to a solution containing $30 \%$ sucrose in $0.1 \mathrm{~m}$ phosphate buffer, $\mathrm{pH} 7.4$, overnight.

Spinal cord segments from control, sham-operated, or injured animals were embedded in tissue freezing medium, longitudinally sectioned (16- $\mu \mathrm{m}$-thick sections) on a cryostat, and mounted on gelatin-coated slides. The sections were permeabilized and blocked with $0.3 \%$ Triton $\mathrm{X}-100 / 10 \%$ normal goat serum in $0.01 \mathrm{M}$ PBS for $30 \mathrm{~min}$. Primary antibodies, activated caspase-3 (1:100, polyclonal antibody; Sigma) and CC-1 (1:100, monoclonal antibody; Oncogene Sciences, Uniondale, $\mathrm{NY}$ ), were applied to the sections overnight at $4^{\circ} \mathrm{C}$. On the following day, the sections were incubated with fluorescein-conjugated goat anti-rabbit (FITC) and rhodamine-conjugated rabbit anti-mouse (rhodamine-Bisothiocyanate) antibodies. Slides were mounted and examined with a 
Zeiss (Oberkochen, Germany) fluorescence microscope (Axiovert 200). In control sections, the primary antibody was substituted by $1 \%$ normal mouse serum.

\section{Stereological analysis}

Total oligodendrocyte or neuron number in the dorsal funiculus or gray matter was assessed using a computer-based stereology system (StereoInvestigator; MicroBrightField, Williston, VT). Neuron and oligodendrocyte numbers were estimated with the optical fractionator (West et al., 1991) $8 \mathrm{~d}$ after SCI. CC-1- and NeuN-positive cells in six equally spaced $30 \mu \mathrm{m}$ sections in a 1 mm block 3.5-4.5 $\mathrm{mm}$ rostral and 3.5-4.5 mm caudal to the epicenter were counted in the dorsal column and the gray matter, respectively. CC-1-positive cells were only counted when the cell body and proximal processes were darkly labeled and were within the inclusive zone of each dissector frame. NeuN-positive cells whose nucleus top came into focus within the inclusive zone of each dissector frame were counted. Results were reported in units of density (cells per cubic millimeter).

\section{Statistical analyses}

Differences among groups were analyzed by one-way ANOVA followed by post hoc Tukey's test.

\section{Results}

Methylprednisolone attenuates oligodendrocyte but not neuronal cell death via glucocorticoid receptors

To determine whether MP has direct neuroprotective activities, we treated cultures of neurons or oligodendrocytes with 200 $\mu \mathrm{M}$ AMPA and $100 \mu \mathrm{M}$ cyclothiazide (for sustained activation of AMPA receptors) or $0.2 \mu \mathrm{M}$ STP. The cells were assessed for death $24 \mathrm{~h}$ after treatment, by LDH release. Both AMPA and STP induced significant cell death within this time period. MP treatment $(1 \mu \mathrm{M})$ attenuated oligodendrocyte (Fig. 1A) but not neuronal (Fig. 1C) cell death, whereas the caspase inhibitor $\mathrm{zVAD}$ [benzyloxycarbonyl-Val-Ala-Asp(OMe)-

fluoromethylketone] $(50 \mu \mathrm{M})$ attenuated cell death for both cell types (Fig. 1A,C). MP attenuated STPinduced oligodendrocyte cell death over a wide range of concentrations; significant reductions in LDH release were detected at 30 nM with maximal effect at $1 \mu \mathrm{M}($ Fig. $1 B)$. However, at these same doses, MP had no effect on STP-induced neuronal death (Fig. $1 D)$, suggesting a selective protective effect in oligodendrocytes.

To determine whether the protective actions of MP in oligodendrocytes were receptor mediated, we added the glucocorticoid receptor antagonist (11,17)-11-[4-(dimethylamino)phenyl]-17-hydroxy-17-(1-propynyl)estra-4,9-dien-3-one (RU486) to STP-treated oligodendrocytes to examine its effect on cell death. In a dose-dependent manner, RU486 antagonized the protective effect of MP with maximal effect at 1-3 $\mu \mathrm{M}$ (Fig. $2 A$ ). RU486 alone had no effect on cell death. To confirm the specific pharmacological effect of RU486 on GR, we also used two different siRNAs to knockdown GR expression. Both GR siRNAs resulted in an attenuation of the protective activity of MP (Fig. 2 B), concomitant with knockdown of GR mRNA (Fig. 2C). These results suggest that MP selectively protects oligodendrocytes (but not neurons) from injury via a glucocorticoid receptor-dependent mechanism.

\section{Glucocorticoid agonists attenuate oligodendrocyte apoptosis} Previous studies have demonstrated that MP exerts protective effects in other cell types by modulating apoptotic regulators (Chang et al., 1997; Bailly-Maitre et al., 2001; Messmer et al., 2001). We sought to determine whether the protective activity of MP in oligodendrocytes were mediated through a similar mechanism. Oligodendrocytes treated with AMPA demonstrated classical features of apoptosis, including downregulation of the antiapoptotic regulator $\mathrm{Bcl}-\mathrm{x}_{\mathrm{L}}$ (Fig. $3 A$ ), caspase-3 activation (Fig. $3 A, B$ ), and DNA fragmentation (Fig. $3 C$ ), consistent with previous reports (Liu et al., 2002; Sanchez-Gomez et al., 2003). Furthermore, as demonstrated above, oligodendrocytes died after exposure to STP (Fig. $1 A, B$ ), a nonselective inhibitor of protein 

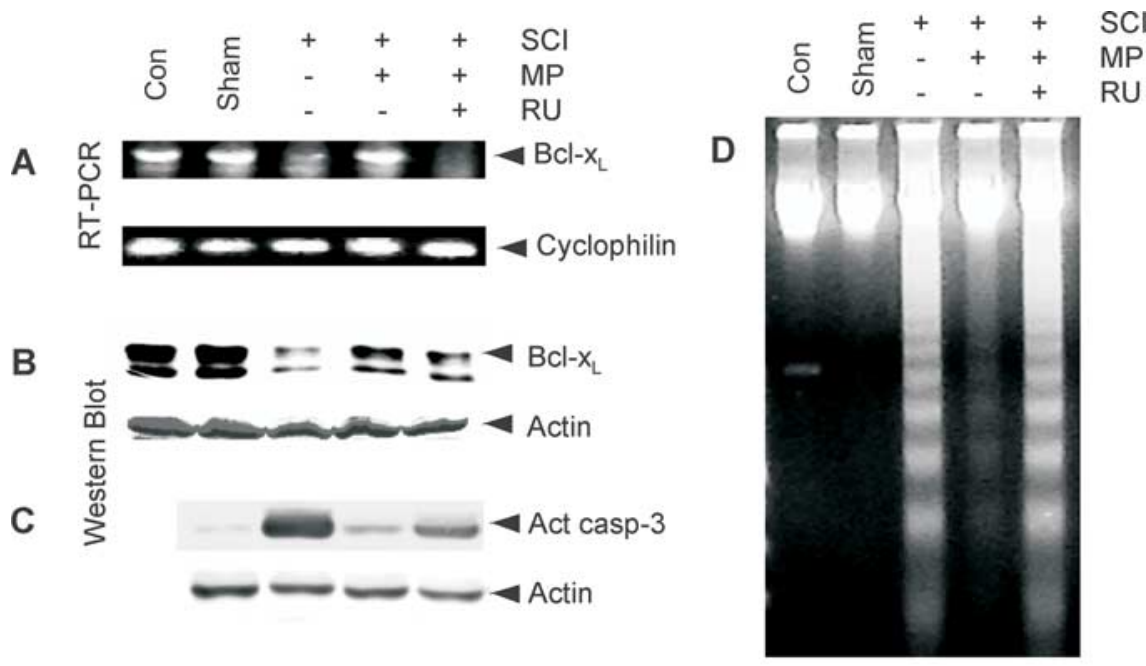

E
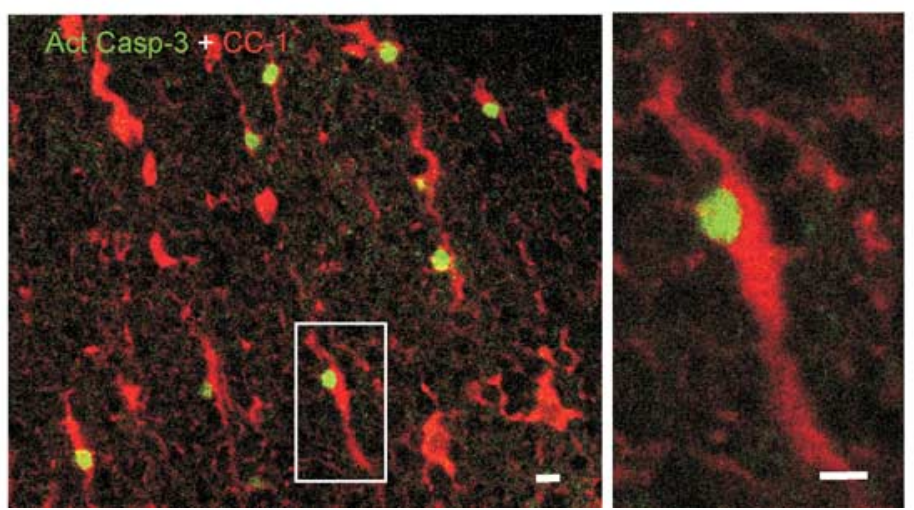

Figure 4. MP inhibits apoptosis after rat SCl. Groups of rats were subjected to no surgery (Con), sham surgery, SCl, SCI plus MP (30 mg/kg, i.v., 15 min before SCl), or SCl plus MP plus RU486 (RU; $15 \mathrm{mg} / \mathrm{kg}$, i.p., $30 \mathrm{~min}$ before $\mathrm{SCl}$ ) as indicated. At $24 \mathrm{~h}$ after surgery, spinal cords were removed, and RT-PCR was performed to measure $B C l-x_{L}$ mRNA $(\boldsymbol{A})$; Western blot was performed to measure $B C l-x_{L}(B)$ and activated caspase-3 (Act casp-3; $\boldsymbol{C}$. Spinal cord extracts were also run on a DNA gel to assess DNA laddering (D). Sections from contused spinal cords were immunostained for activated caspase-3 (green) and CC -1 (red) $8 \mathrm{~d}$ after surgery, demonstrating colabeling (left panel, low power; right panel, high power; scale bars, $10 \mu \mathrm{m})(\boldsymbol{E})$. Blots and gels are representative of at least three independent replicates.

kinase often used to induce apoptosis. Treatment with $1 \mu \mathrm{M} \mathrm{MP}$ increased $\mathrm{Bcl}-\mathrm{x}_{\mathrm{L}}$ expression, decreased caspase- 3 activation and DNA fragmentation, and attenuated cell death (Fig. $3 A-D$ ). RU486 $(1 \mu \mathrm{M})$ antagonized the effects of MP on the apoptotic mediators and reversed the protective effects of MP (Fig. 3A-D). Furthermore, DEX $(1 \mu \mathrm{M})$ also demonstrated similar protective effects on oligodendrocytes, attenuating AMPA-induced apoptosis. MP did not rescue STP-treated neurons (Fig. $1 C, D$ ), nor did it increase Bcl- $\mathrm{x}_{\mathrm{L}}$ levels in these cells (Fig. 3E). Collectively, these results suggest that glucocorticoid agonists inhibit oligodendrocyte apoptosis via glucocorticoid receptor-mediated inhibition of apoptotic mediators.

\section{Methylprednisolone inhibits SCI-induced apoptosis}

We sought to examine whether MP could have similar antiapoptotic activity after SCI in a rat model. Groups of rats were subjected to SCI using the NYU Impactor (see Materials and Methods), and the molecular signatures of apoptosis were examined $24 \mathrm{~h}$ after contusion. In agreement with previous reports (Qiu et al., 2001; Nesic-Taylor et al., 2005), we found that SCI decreased Bcl- $\mathrm{x}_{\mathrm{L}}$ mRNA (Fig. 4A) and protein (Fig. 4B), increased caspase-3 activation (Fig. 4C), and induced DNA laddering (Fig. $4 D$ ), similar to our in vitro findings above. All of these changes in the apoptotic indicators were reversed when rats were treated with MP $(30 \mathrm{mg} / \mathrm{kg}$, i.v.) $15 \mathrm{~min}$ after SCI. Moreover, the effects of MP were abrogated by RU $486(15 \mathrm{mg} / \mathrm{kg}$, i.p.) $30 \mathrm{~min}$ before SCI (Fig. $4 A-D$ ), suggesting that the antiapoptotic effects were GR mediated. Prominent among cells that demonstrated activated caspase- 3 immunoreactivity (Act casp-3) were oligodendrocytes that colabeled with CC-1 (Fig. 4E). Activated caspase- 3 immunostaining was absent in sham-operated animals (data not shown).

\section{Methylprednisolone selectively attenuates oligodendrocyte cell death and demyelination after SCI}

To determine whether MP demonstrated selective protection of oligodendrocytes after SCI (as found in our in vitro models), we used unbiased stereology to quantify surviving oligodendrocytes and neurons $8 \mathrm{~d}$ after SCI, to allow time for degenerating cells to disappear. Groups of rats were subjected to sham surgery, SCI (using NYU Impactor; see Materials and Methods), treatment with MP (30 mg/kg, i.v.) $15 \mathrm{~min}$ after SCI, or treatment with MP (15 min before) and RU486 (15 mg/kg, i.p.) $30 \mathrm{~min}$ before SCI as indicated (Fig. 5). Because of the gross morphological alterations at the epicenter of the contusion, we counted surviving cells 3.5$4.5 \mathrm{~mm}$ from the epicenter (both rostral and caudal), specifically counting CC-1immunostained oligodendrocytes in the dorsal columns or NeuN-immunostained neurons in the gray matter (Fig. 5A). Eight days after SCI, the number of surviving oligodendrocytes in the dorsal columns was significantly decreased compared with sham-operated controls. MP treatment (30 mg/kg, i.v.) attenuated this SCI-induced oligodendrocyte death, and RU486 (15 $\mathrm{mg} / \mathrm{kg}$, i.p.) reversed the protective effect of MP (Fig. $5 B$ ). RU486 alone had no effect on cell number. SCI also significantly decreased neuronal number in the gray matter; however, MP had no effect on neuronal cell survival (Fig. $5 C$ ). These results suggest that MP selectively attenuates oligodendrocyte but not neuronal cell death after SCI. Furthermore, this protective effect appears to be mediated via the glucocorticoid receptor. A similar trend was observed in spinal cord homogenates ( $8 \mathrm{~d}$ after contusion) subjected to Western blotting, using anti-NeuN and anti-MBP antibodies. SCI reduced expression of both antigens, MP rescued MBP (14 kDa isoform) but not NeuN expression, and RU486 antagonized this effect (Fig. 6A-D).

One consequence of SCI and oligodendrocyte death (which can occur at sites distant from the epicenter) is demyelination in and around the contusion cavity. To determine whether MP altered the extent of demyelination after SCI, we used Luxol fast blue staining in groups of rats treated with vehicle, MP, or MP plus RU486 (Fig. 7A). After SCI, a relatively large volume of demyelination was observed $\left(\sim 7 \mathrm{~mm}^{3}\right)$. Treatment with MP significantly reduced this volume of demyelination, an effect that was reversed by RU486 (Fig. 7B). These data suggest that MP 
A
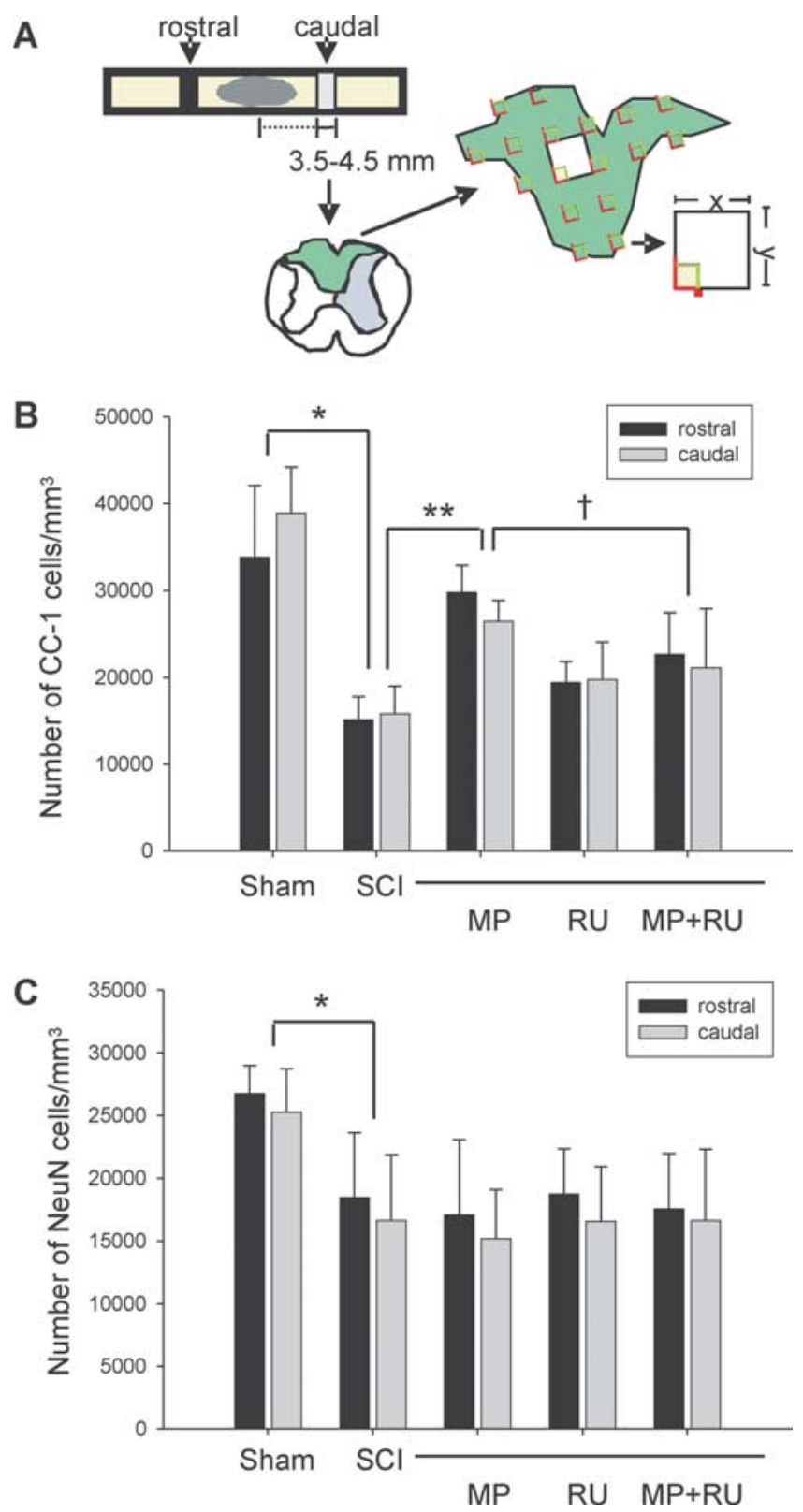

Figure 5. MP attenuates oligodendrocyte but not neuronal cell death after rat $\mathrm{SCl}$. Groups of rats were subjected to sham surgery $(n=7), \mathrm{SCl}(n=9)$, treatment with $\mathrm{MP}(30 \mathrm{mg} / \mathrm{kg}$, i.v.; $n=6) 15 \mathrm{~min}$ after SCl, RU486 (RU; $15 \mathrm{mg} / \mathrm{kg}$, i.p.; $n=6) 30 \mathrm{~min}$ before SCl, or MP and RU486 $(n=12)$. Unbiased stereology was used to count cells in equally spaced transverse sections located 3.5-4.5 mm rostral and caudal to the epicenter $(\boldsymbol{A})$, as described in Materials and Methods. Oligodendrocytes (CC-1-positive cells) (B) or neurons (NeuN-positive cells) (C) were counted $8 \mathrm{~d}$ after $\mathrm{SCl}$ and expressed as mean \pm SD. Statistical tests were performed on total cell counts (rostral plus caudal) and are significantly different as indicated: ${ }^{*} p<0.001$ for sham versus SCl; ${ }^{* *} p<0.001$ for $\mathrm{SCl}$ versus SCI plus MP; ${ }^{\dagger} p<0.05$ for SCl plus MP versus SCl plus MP plus RU486 (ANOVA with post hoc Tukey's test).

reduces SCI-induced demyelination by attenuating oligodendrocyte cell death via the glucocorticoid receptor.

\section{Discussion}

This study provides evidence that MP selectively attenuates oligodendrocyte apoptosis after injury, via a glucocorticoid receptor-mediated mechanism. In vitro, we demonstrated that MP attenuates oligodendrocyte apoptosis induced by AMPA and staurosporine, whereas neuronal apoptosis was unaffected at identical doses. Moreover, this protective effect on oligodendro- cytes was inhibited by RU486 and GR-targeted siRNA, suggesting a receptor-mediated mechanism. Oligodendrocyte-selective protection was also observed after rat SCI in vivo, in which MP treatment selectively attenuated oligodendrocyte cell death without affecting neuronal survival via a glucocorticoid receptormediated mechanism. Furthermore, MP reversed apoptotic molecular signatures in oligodendrocytes in vitro, and, after SCI in vivo, downregulation of $\mathrm{Bcl}-\mathrm{x}_{\mathrm{L}}$, activation of caspase-3, and DNA fragmentation was attenuated by MP.

Although better known for its proapoptotic activity in a variety of inflammatory cells, MP has also been reported to exert antiapoptotic activity in a few cell types, including TMK-1 cells (Chang et al., 1997), bovine glomerular endothelial cells (Messmer et al., 1999), MCF-7 cells (Messmer et al., 2001), C6 glioma cells (Ni Chonghaile et al., 2006), and primary hepatocytes (Bailly-Maitre et al., 2001). Therefore, our novel finding that MP exerts antiapoptotic activity in oligodendrocytes is consistent with these previous reports. Our findings are also consistent with preliminary evidence, which suggested that MP may exert antiapoptotic activity after SCI in rats (Vaquero et al., 2006), although this study did not report the selective antiapoptotic activity in oligodendrocytes.

In our studies, we found that MP inhibits $\mathrm{Bcl}-\mathrm{x}_{\mathrm{L}}$ downregulation after injury stimuli, along with downstream events (caspase- 3 activation and DNA laddering). $B c l-x_{L}$, which resides on the mitochondrial outer membrane, is an important antiapoptotic regulator involved in the cell-intrinsic apoptotic pathway. It is believed to exert its antiapoptotic action by contributing to the maintenance of membrane integrity (thereby preventing the release of proapoptotic signaling molecules from the inner mitochondrial membrane) (for review, see Lindsten et al., 2005). Endogenous Bcl- $\mathrm{x}_{\mathrm{L}}$ is highly expressed throughout the postnatal CNS (Gonzalez-Garcia et al., 1994; Krajewska et al., 2002), suggesting an important role in maintaining survival of adult neural cells, under physiological and pathological conditions. Indeed, the infusion of a Bcl-xL fusion protein after SCI in rats promoted neuronal survival (Nesic-Taylor et al., 2005).

The glucocorticoid receptor is ubiquitously expressed in cells throughout the nervous system, including neurons, astrocytes, and oligodendrocytes in the brain (Fuxe et al., 1985b) and spinal cord (Fuxe et al., 1985a). After SCI, glucocorticoid receptor expression is upregulated in all of these cell types, with peak expression occurring $8 \mathrm{~h}$ after contusion (Yan et al., 1999). In the inactive state, glucocorticoid receptors (intracellular receptors) reside predominantly in the cytoplasm, associated with other proteins (Vedeckis, 1983; Mendel et al., 1986; Sanchez et al., 1987). During activation via steroid binding, these proteins dissociate, and the steroid-receptor complex dimerizes and translocates to the nucleus, in which it binds to specific DNA consensus sequences, termed glucocorticoid response elements (GREs) (Tsai et al., 1988) to participate directly in gene regulation (Yamamoto, 1985). The $b c l$-x gene has several GRE consensus sequences in the promoter region (Gascoyne et al., 2003), suggesting a potential mechanism for its induction by MP in oligodendrocytes. Despite the expression of glucocorticoid receptors in neurons (Fuxe et al., 1985a,b), MP did not exert protective effects on cortical neurons in vitro or spinal cord neurons after SCI in vivo. Moreover, in our in vitro studies, $\mathrm{MP}$ did not induce $\mathrm{Bcl}-\mathrm{x}_{\mathrm{L}}$ expression in neurons, although it was induced in oligodendrocytes. These findings suggest that the cell-type-specific activities of MP may be mediated by downstream signaling events, which are likely to be different in neurons versus oligodendrocytes.

Although RU486 was first developed as a specific glucocorti- 
A

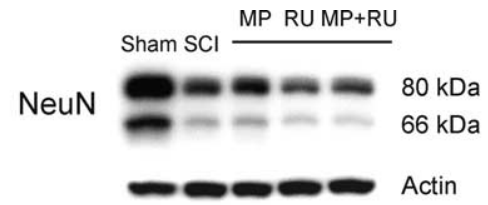

B

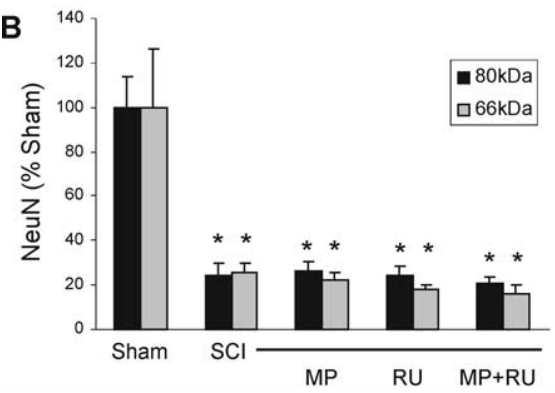

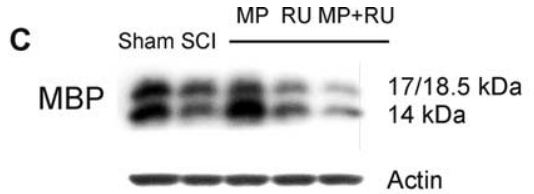

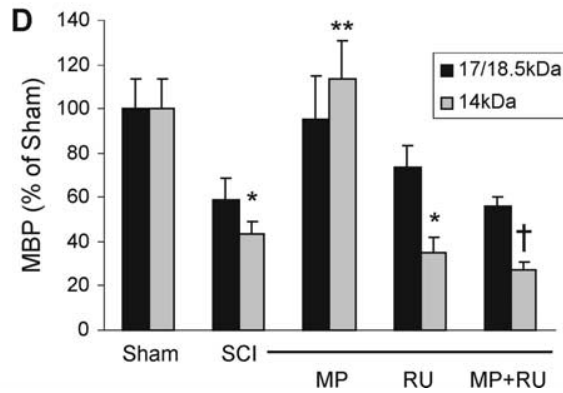

Figure 6. MP rescues MBP but not NeuN expression after $\mathrm{SCl}$. Spinal cord homogenates from rats subjected to sham surgery, SCl, SCI plus MP, SCI plus RU486 (RU), or SCI plus MP plus RU486 ( $n=4$ per group) were immunoblotted using anti-NeuN $(\boldsymbol{A})$ or anti-MBP $(\boldsymbol{C})$ antibodies, $8 \mathrm{~d}$ after surgery. Bands from blots were quantified by densitometry, normalized to actin, and expressed as mean \pm SEM (percentage sham). NeuN expression was decreased after SCl, but neither MP, RU486, nor MP plus RU486 had any effect on expression (B). MBP expression (14 kDa isoform) was decreased after $\mathrm{SCl}$ but rescued by MP and antagonized by RU486 (D). ${ }^{*} p<0.001$ for sham versus SCl; ${ }^{* *} p<0.005$ for SCI versus SCI plus MP; ${ }^{\dagger} p<0.001$ for SCI plus MP versus SCI plus MP plus RU486 (ANOVA with post hoc Tukey's test).

A

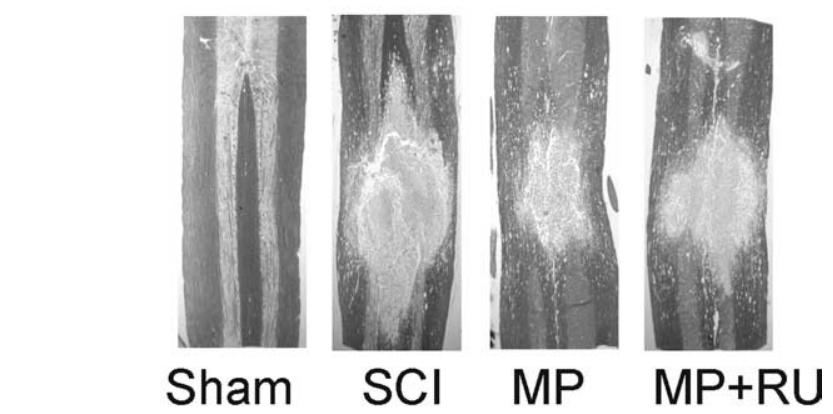

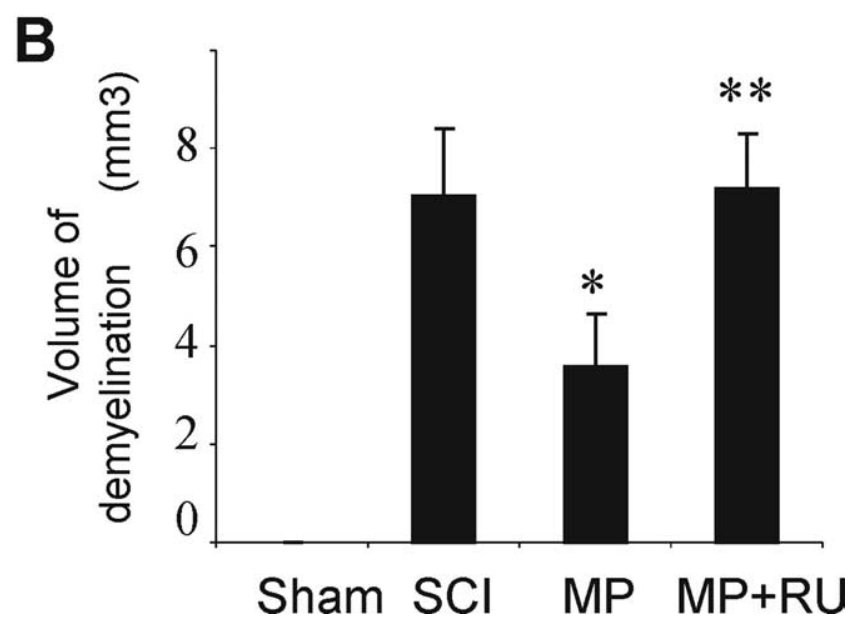

Figure 7. MP reduces $\mathrm{SCl}$-induced demyelination via a receptor-mediated mechanism. Spinal cords from groups of six rats subjected to sham surgery, SCI, SCI plus MP, or SCI plus MP plus RU486 were extracted, longitudinally sectioned, and stained with Luxol fast blue $(\boldsymbol{A})$. The volume of demyelination was quantified and expressed as mean $\pm \mathrm{SD}(\boldsymbol{B}) .{ }^{*} p<0.001$ for $\mathrm{SCl}$ versus SCI plus MP; ${ }^{* *} p<0.001$ for SCI plus MP versus SCI plus MP plus RU486 (AN0VA with post hoc Tukey's test). coid antagonist (Teutsch et al., 1981), subsequent characterization revealed several other activities. RU486 binds avidly to but weakly activates GR, giving it agonist/antagonist properties (Bourgeois et al., 1984). In addition, RU486 antagonizes the progesterone receptor (Teutsch et al., 1981; Philibert, 1984), which is the basis for its contraceptive activity. In our studies, we found that RU486 antagonized the protective activities of MP in oligodendrocytes treated with STP in vitro and after spinal cord injury in vivo, suggesting that the protective effects of MP were mediated via GR. To rule out the possibility that RU486 antagonized progesterone-mediated protective effects, we examined the effect of RU486 administered alone after STP-induced cell death or after SCI. RU486 alone did not have any effect on cell survival either in vitro or in vivo.

Although MP is not Food and Drug Administration approved for use in acute SCI, it is commonly used in this setting based on the results of several randomized controlled trials (Bracken et al., 1990, 1997). However, many have questioned the efficacy of MP because of its marginal effects and criticisms of study design and interpretation (Nesathurai, 1998; Coleman et al., 2000; Hurlbert, 2000; Sayer et al., 2006). Moreover, there is concern that MP may have detrimental effects that may outweigh its marginal clinical benefits (Nesathurai, 1998; Sayer et al., 2006). There may still be utility in understanding mechanisms of the protective effects of MP with hopes of developing interventions that promote protective effects but minimize adverse effects.

That MP is selectively protective for oligodendrocytes is intuitively appealing, because its clinical indications involve several CNS disorders involving white matter injury. Despite its marginal efficacy in SCI, MP is the mainstay of therapy for a variety of demyelinating disorders, including multiple sclerosis and acute disseminated encephalomyelitis. Demyelination after SCI is thought to play an important role in disability and has been proposed to be an important target for therapeutic intervention (for review, see McDonald and Belegu, 2006). Although current opinion favors an antioxidant or anti-inflammatory mechanism, based on our study we raise the possibility that the mechanisms of action of MP may also involve direct antiapoptotic activity in oligodendrocytes. This novel mechanism may have implications for the use of MP in other disorders involving white matter injury.

\section{References}

Anderson DK, Means ED (1985) Iron-induced lipid peroxidation in spinal cord: protection with mannitol and methylprednisolone. J Free Radic Biol Med 1:59-64.

Arzt E, Sauer J, Pollmacher T, Labeur M, Holsboer F, Reul JM, Stalla GK (1994) Glucocorticoids suppress interleukin-1 receptor antagonist synthesis following induction by endotoxin. Endocrinology 134:672-677.

Bailly-Maitre B, de Sousa G, Boulukos K, Gugenheim J, Rahmani R (2001) Dexamethasone inhibits spontaneous apoptosis in primary cultures of human and rat hepatocytes via Bcl-2 and Bcl-xL induction. Cell Death Differ 8:279-288.

Barnes PJ (1998) Anti-inflammatory actions of glucocorticoids: molecular mechanisms. Clin Sci (Lond) 94:557-572.

Basso DM, Beattie MS, Bresnahan JC, Anderson DK, Faden AI, Gruner JA, 
Holford TR, Hsu CY, Noble LJ, Nockels R, Perot PL, Salzman SK, Young W (1996) MASCIS evaluation of open field locomotor scores: effects of experience and teamwork on reliability. Multicenter Animal Spinal Cord Injury Study. J Neurotrauma 13:343-359.

Bourgeois S, Pfahl M, Baulieu EE (1984) DNA binding properties of glucocorticosteroid receptors bound to the steroid antagonist RU-486. EMBO J 3:751-755.

Bracken MB (1991) Treatment of acute spinal cord injury with methylprednisolone: results of a multicenter, randomized clinical trial. J Neurotrauma 8 [Suppl 1]:S47-S50; discussion S51-S42.

Bracken MB, Shepard MJ, Collins WF, Holford TR, Young W, Baskin DS, Eisenberg HM, Flamm E, Leo-Summers L, Maroon J, Marshall LF, Perot PL, Piepmeier J, Sonntag VK, Wagner FC, Wilberger JE, Winn HR (1990) A randomized, controlled trial of methylprednisolone or naloxone in the treatment of acute spinal-cord injury. Results of the Second National Acute Spinal Cord Injury Study. N Engl J Med 322:1405-1411.

Bracken MB, Shepard MJ, Holford TR, Leo-Summers L, Aldrich EF, Fazl M, Fehlings M, Herr DL, Hitchon PW, Marshall LF, Nockels RP, Pascale V, Perot Jr PL, Piepmeier J, Sonntag VK, Wagner F, Wilberger JE, Winn HR, Young W (1997) Administration of methylprednisolone for 24 or 48 hours or tirilazad mesylate for 48 hours in the treatment of acute spinal cord injury. Results of the Third National Acute Spinal Cord Injury Randomized Controlled Trial. National Acute Spinal Cord Injury Study. JAMA 277:1597-1604.

Brenner T, Yamin A, Gallily R (1994) Mycoplasma triggering of nitric oxide production by central nervous system glial cells and its inhibition by glucocorticoids. Brain Res 641:51-56.

Chang TC, Hung MW, Jiang SY, Chu JT, Chu LL, Tsai LC (1997) Dexamethasone suppresses apoptosis in a human gastric cancer cell line through modulation of bcl-x gene expression. FEBS Lett 415:11-15.

Coleman WP, Benzel D, Cahill DW, Ducker T, Geisler F, Green B, Gropper MR, Goffin J, Madsen III PW, Maiman DJ, Ondra SL, Rosner M, Sasso RC, Trost GR, Zeidman S (2000) A critical appraisal of the reporting of the National Acute Spinal Cord Injury Studies (II and III) of methylprednisolone in acute spinal cord injury. J Spinal Disord 13:185-199.

Crowe MJ, Bresnahan JC, Shuman SL, Masters JN, Beattie MS (1997) Apoptosis and delayed degeneration after spinal cord injury in rats and monkeys. Nat Med 3:73-76.

Demopoulos HB, Flamm ES, Seligman ML, Pietronigro DD, Tomasula J, DeCrescito V (1982) Further studies on free-radical pathology in the major central nervous system disorders: effect of very high doses of methylprednisolone on the functional outcome, morphology, and chemistry of experimental spinal cord impact injury. Can J Physiol Pharmacol 60:1415-1424.

Emery E, Aldana P, Bunge MB, Puckett W, Srinivasan A, Keane RW, Bethea J, Levi AD (1998) Apoptosis after traumatic human spinal cord injury. J Neurosurg 89:911-920.

Funk JO, Ernst M, Schonharting MM, Zabel P (1995) Pentoxifylline exerts synergistic immunomodulatory effects in combination with dexamethasone or cyclosporin A. Int J Immunopharmacol 17:1007-1016.

Fuxe K, Harfstrand A, Agnati LF, Yu ZY, Cintra A, Wikstrom AC, Okret S, Cantoni E, Gustafsson JA (1985a) Immunocytochemical studies on the localization of glucocorticoid receptor immunoreactive nerve cells in the lower brain stem and spinal cord of the male rat using a monoclonal antibody against rat liver glucocorticoid receptor. Neurosci Lett 60:1-6.

Fuxe K, Wikstrom AC, Okret S, Agnati LF, Harfstrand A, Yu ZY, Granholm L, Zoli M, Vale W, Gustafsson JA (1985b) Mapping of glucocorticoid receptor immunoreactive neurons in the rat tel- and diencephalon using a monoclonal antibody against rat liver glucocorticoid receptor. Endocrinology 117:1803-1812.

Gascoyne DM, Kypta RM, Vivanco MM (2003) Glucocorticoids inhibit apoptosis during fibrosarcoma development by transcriptionally activating Bcl-xL. J Biol Chem 278:18022-18029.

Gonzalez-Garcia M, Perez-Ballestero R, Ding L, Duan L, Boise LH, Thompson CB, Nunez G (1994) bcl-XL is the major bcl-x mRNA form expressed during murine development and its product localizes to mitochondria. Development 120:3033-3042.

Hall ED, Braughler JM (1982) Effects of intravenous methylprednisolone on spinal cord lipid peroxidation and $\mathrm{Na}^{+}+\mathrm{K}^{+}$-ATPase activity. Doseresponse analysis during 1st hour after contusion injury in the cat. J Neurosurg 57:247-253.

Hamada Y, Ikata T, Katoh S, Nakauchi K, Niwa M, Kawai Y, Fukuzawa K
(1996) Involvement of an intercellular adhesion molecule 1-dependent pathway in the pathogenesis of secondary changes after spinal cord injury in rats. J Neurochem 66:1525-1531.

Heyderman RS, Klein NJ, Daramola OA, Levin M (1995) Modulation of the endothelial procoagulant response to lipopolysaccharide and tumour necrosis factor-alpha in-vitro: the effects of dexamethasone, pentoxifylline, iloprost and a polyclonal anti-human IL-1 alpha antibody. Inflamm Res 44:275-280.

Holets VR, Hokfelt T, Ude J, Eckert M, Penzlin H, Verhofstad AA, Visser TJ (1987) A comparative study of the immunohistochemical localization of a presumptive proctolin-like peptide, thyrotropin-releasing hormone and 5-hydroxytryptamine in the rat central nervous system. Brain Res 408:141-153.

Hurlbert RJ (2000) Methylprednisolone for acute spinal cord injury: an inappropriate standard of care. J Neurosurg 93:1-7.

Keane RW, Kraydieh S, Lotocki G, Bethea JR, Krajewski S, Reed JC, Dietrich WD (2001) Apoptotic and anti-apoptotic mechanisms following spinal cord injury. J Neuropathol Exp Neurol 60:422-429.

Krajewska M, Mai JK, Zapata JM, Ashwell KW, Schendel SL, Reed JC, Krajewski S (2002) Dynamics of expression of apoptosis-regulatory proteins Bid, Bcl-2, Bcl-X, Bax and Bak during development of murine nervous system. Cell Death Differ 9:145-157.

Lee JT, Xu J, Lee JM, Ku G, Han X, Yang DI, Chen S, Hsu CY (2004) Amyloid-beta peptide induces oligodendrocyte death by activating the neutral sphingomyelinase-ceramide pathway. J Cell Biol 164:123-131.

Li M, Ona VO, Chen M, Kaul M, Tenneti L, Zhang X, Stieg PE, Lipton SA, Friedlander RM (2000) Functional role and therapeutic implications of neuronal caspase-1 and -3 in a mouse model of traumatic spinal cord injury. Neuroscience 99:333-342.

Lindsten T, Zong WX, Thompson CB (2005) Defining the role of the Bcl-2 family of proteins in the nervous system. The Neuroscientist 11:10-15.

Liu HN, Giasson BI, Mushynski WE, Almazan G (2002) AMPA receptormediated toxicity in oligodendrocyte progenitors involves free radical generation and activation of JNK, calpain and caspase 3. J Neurochem $82: 398-409$.

Liu XZ, Xu XM, Hu R, Du C, Zhang SX, McDonald JW, Dong HX, Wu YJ, Fan GS, Jacquin MF, Hsu CY, Choi DW (1997) Neuronal and glial apoptosis after traumatic spinal cord injury. J Neurosci 17:5395-5406.

Lukiw WJ, Pelaez RP, Martinez J, Bazan NG (1998) Budesonide epimer R or dexamethasone selectively inhibit platelet-activating factor-induced or interleukin 1beta-induced DNA binding activity of cis-acting transcription factors and cyclooxygenase-2 gene expression in human epidermal keratinocytes. Proc Natl Acad Sci USA 95:3914-3919.

McDonald JW, Belegu V (2006) Demyelination and remyelination after spinal cord injury. J Neurotrauma 23:345-359.

McEwen ML, Springer JE (2005) A mapping study of caspase-3 activation following acute spinal cord contusion in rats. J Histochem Cytochem 53:809-819.

McTigue DM, Wei P, Stokes BT (2001) Proliferation of NG2-positive cells and altered oligodendrocyte numbers in the contused rat spinal cord. J Neurosci 21:3392-3400.

Mendel DB, Bodwell JE, Gametchu B, Harrison RW, Munck A (1986) Molybdate-stabilized nonactivated glucocorticoid-receptor complexes contain a $90-\mathrm{kDa}$ non-steroid-binding phosphoprotein that is lost on activation. J Biol Chem 261:3758-3763.

Messmer UK, Winkel G, Briner VA, Pfeilschifter J (1999) Glucocorticoids potently block tumour necrosis factor-alpha- and lipopolysaccharideinduced apoptotic cell death in bovine glomerular endothelial cells upstream of caspase 3 activation. Br J Pharmacol 127:1633-1640.

Messmer UK, Pereda-Fernandez C, Manderscheid M, Pfeilschifter J (2001) Dexamethasone inhibits TNF-alpha-induced apoptosis and IAP protein downregulation in MCF-7 cells. Br J Pharmacol 133:467-476.

Nesathurai S (1998) Steroids and spinal cord injury: revisiting the NASCIS 2 and NASCIS 3 trials. J Trauma 45:1088-1093.

Nesic-Taylor O, Cittelly D, Ye Z, Xu GY, Unabia G, Lee JC, Svrakic NM, Liu $\mathrm{XH}$, Youle RJ, Wood TG, McAdoo D, Westlund KN, Hulsebosch CE, Perez-Polo JR (2005) Exogenous Bcl-xL fusion protein spares neurons after spinal cord injury. J Neurosci Res 79:628-637.

Ni Chonghaile T, Concannon CG, Szegezdi E, Gorman AM, Samali A (2006) Dexamethasone inhibits apoptosis in C6 glioma cells through increased expression of Bcl-XL. Apoptosis 11:1247-1255.

Perkins DJ, Kniss DA (1997) Tumor necrosis factor-alpha promotes sus- 
tained cyclooxygenase- 2 expression: attenuation by dexamethasone and NSAIDs. Prostaglandins 54:727-743.

Philibert D (1984) RU-3486: an original multifaceted antihormones in vivo. In: Adrenal steroid antagonism, pp 77-101. New York: de Gruyter.

Qiu J, Nesic O, Ye Z, Rea H, Westlund KN, Xu GY, McAdoo D, Hulsebosch CE, Perez-Polo JR (2001) Bcl-xL expression after contusion to the rat spinal cord. J Neurotrauma 18:1267-1278.

Rose K, Christine CW, Choi DW (1990) Magnesium removal induces paroxysmal neuronal firing and NMDA receptor-mediated neuronal degeneration in cortical cultures. Neurosci Lett 115:313-317.

Sanchez-Gomez MV, Alberdi E, Ibarretxe G, Torre I, Matute C (2003) Caspase-dependent and caspase-independent oligodendrocyte death mediated by AMPA and kainate receptors. J Neurosci 23:9519-9528.

Sanchez ER, Meshinchi S, Schlesinger MJ, Pratt WB (1987) Demonstration that the 90-kilodalton heat shock protein is bound to the glucocorticoid receptor in its $9 \mathrm{~S}$ nondeoxynucleic acid binding form. Mol Endocrinol 1:908-912.

Sayer FT, Kronvall E, Nilsson OG (2006) Methylprednisolone treatment in acute spinal cord injury: the myth challenged through a structured analysis of published literature. Spine J 6:335-343.

Schmidt M, Pauels HG, Lugering N, Lugering A, Domschke W, Kucharzik T (1999) Glucocorticoids induce apoptosis in human monocytes: potential role of IL-1 beta. J Immunol 163:3484-3490.

Shuman SL, Bresnahan JC, Beattie MS (1997) Apoptosis of microglia and oligodendrocytes after spinal cord contusion in rats. J Neurosci Res $50: 798-808$.

Sikora U (1966) On cutaneous emphysemas in the maxillo-facial region (in German). Dtsch Stomatol 16:648-652.

Springer JE, Azbill RD, Knapp PE (1999) Activation of the caspase-3 apoptotic cascade in traumatic spinal cord injury. Nat Med 5:943-946.

Springer JE, Nottingham SA, McEwen ML, Azbill RD, Jin Y (2001) Caspase-3 apoptotic signaling following injury to the central nervous system. Clin Chem Lab Med 39:299-307.

Teutsch G, Costerousse G, Deraedt R, Benzoni J, Fortin M, Philibert D (1981) 17 alpha-alkynyl-11 beta, 17-dihydroxyandrostane derivatives: a new class of potent glucocorticoids. Steroids 38:651-665.

Tsai SY, Carlstedt-Duke J, Weigel NL, Dahlman K, Gustafsson JA, Tsai MJ, O'Malley BW (1988) Molecular interactions of steroid hormone receptor with its enhancer element: evidence for receptor dimer formation. Cell 55:361-369.

van de Stolpe A, Caldenhoven E, Stade BG, Koenderman L, Raaijmakers JA, Johnson JP, van der Saag PT (1994) 12-O-tetradecanoylphorbol-13acetate- and tumor necrosis factor alpha-mediated induction of intercellular adhesion molecule-1 is inhibited by dexamethasone. Functional analysis of the human intercellular adhesion molecular-1 promoter. J Biol Chem 269:6185-6192.

Vaquero J, Zurita M, Oya S, Aguayo C, Bonilla C (2006) Early administration of methylprednisolone decreases apoptotic cell death after spinal cord injury. Histol Histopathol 21:1091-1102.

Vedeckis WV (1983) Subunit dissociation as a possible mechanism of glucocorticoid receptor activation. Biochemistry 22:1983-1989.

West MJ, Slomianka L, Gundersen HJ (1991) Unbiased stereological estimation of the total number of neurons in thesubdivisions of the rat hippocampus using the optical fractionator. Anat Rec 231:482-497.

Xu J, Hsu CY, Junker H, Chao S, Hogan EL, Chao J (1991) Kininogen and kinin in experimental spinal cord injury. J Neurochem 57:975-980.

Xu J, Qu ZX, Moore SA, Hsu CY, Hogan EL (1992) Receptor-linked hydrolysis of phosphoinositides and production of prostacyclin in cerebral endothelial cells. J Neurochem 58:1930-1935.

Xu J, Wu Y, He L, Yang Y, Moore SA, Hsu CY (1997) Regulation of cytokine-induced iNOS expression by a hairpin oligonucleotide in murine cerebral endothelial cells. Biochem Biophys Res Commun 235:394-397.

Xu J, Fan G, Chen S, Wu Y, Xu XM, Hsu CY (1998a) Methylprednisolone inhibition of TNF-alpha expression and NF-kB activation after spinal cord injury in rats. Brain Res Mol Brain Res 59:135-142.

Xu J, Yeh CH, Chen S, He L, Sensi SL, Canzoniero LM, Choi DW, Hsu CY (1998b) Involvement of de novo ceramide biosynthesis in tumor necrosis factor-alpha/cycloheximide-induced cerebral endothelial cell death. J Biol Chem 273:16521-16526.

Xu JA, Hsu CY, Liu TH, Hogan EL, Perot Jr PL, Tai HH (1990) Leukotriene B4 release and polymorphonuclear cell infiltration in spinal cord injury. J Neurochem 55:907-912.

Xu XM, Guenard V, Kleitman N, Aebischer P, Bunge MB (1995) A combination of BDNF and NT-3 promotes supraspinal axonal regeneration into Schwann cell grafts in adult rat thoracic spinal cord. Exp Neurol 134:261-272.

Yamamoto KR (1985) Steroid receptor regulated transcription of specific genes and gene networks. Annu Rev Genet 19:209-252.

Yan P, Xu J, Li Q, Chen S, Kim GM, Hsu CY, Xu XM (1999) Glucocorticoid receptor expression in the spinal cord after traumatic injury in adult rats. J Neurosci 19:9355-9363.

Yong C, Arnold PM, Zoubine MN, Citron BA, Watanabe I, Berman NE, Festoff BW (1998) Apoptosis in cellular compartments of rat spinal cord after severe contusion injury. J Neurotrauma 15:459-472.

Zhang SC, Ge B, Duncan ID (1999) Adult brain retains the potential to generate oligodendroglial progenitors with extensive myelination capacity. Proc Natl Acad Sci USA 96:4089-4094. 